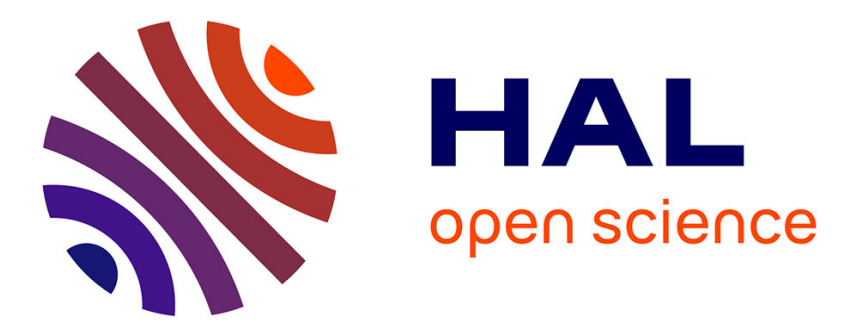

\title{
The importance of land use change in the environmental balance of biofuels
}

\author{
Wassim Ben Aoun, Benoit Gabrielle, Bruno Gagnepain
}

\section{To cite this version:}

Wassim Ben Aoun, Benoit Gabrielle, Bruno Gagnepain. The importance of land use change in the environmental balance of biofuels. OCL Oléagineux Corps Gras Lipides, 2013, article no D505, 12 p. open access. 10.1051/ocl/2013027 . hal-01003402

\section{HAL Id: hal-01003402 \\ https://hal.science/hal-01003402}

Submitted on 28 May 2020

HAL is a multi-disciplinary open access archive for the deposit and dissemination of scientific research documents, whether they are published or not. The documents may come from teaching and research institutions in France or abroad, or from public or private research centers.
L'archive ouverte pluridisciplinaire HAL, est destinée au dépôt et à la diffusion de documents scientifiques de niveau recherche, publiés ou non, émanant des établissements d'enseignement et de recherche français ou étrangers, des laboratoires publics ou privés. 


\title{
BIODIESEL ET HUILES HYDROTRAITÉES
}

\section{The importance of land use change in the environmental balance of biofuels}

\author{
Wassim Ben Aoun ${ }^{1, a}$, Benoît Gabrielle ${ }^{1}$ and Bruno Gagnepain ${ }^{2}$ \\ 1 AgroParisTech, INRA, UMR 1091 Environnement et Grandes Cultures, 78850 Thiverval-Grignon, France \\ 2 Service Bioressources, Agence de l'Environnement et de la Maîtrise de l'Energie (ADEME), 20, avenue du Grésillé, \\ BP 90406, 49004 Angers Cedex 01, France
}

Received 30 April 2013 - Accepted 28 May 2013

\begin{abstract}
The potential of first generation biofuels to mitigate climate change is still largely debated in the scientific and policy-making arenas. It is currently assessed through life cycle assessment (LCA), a method for accounting for the greenhouse gas (GHG) emissions of a given product from "cradle-to-grave", which is widely used to aid decision making on environmental issues. Although LCA is standardized, its application to biofuels leads to inconclusive results often fraught by a high variability and uncertainty. This is due to differences in quantifying the environmental impacts of feedstock production, and the difficulties encountered when considering land use changes (LUC) effects. The occurrence of LUC mechanisms is in part the consequence of policies supporting the use of biofuels in the transport sector, which implicitly increases the competition between various possible uses of land worldwide. Here, we review the methodologies recently put forward to include LUC effects in LCAs, and examples from the US, Europe and France. These cross analysis show that LCA needs to be adapted and combined to other tools such as economic modeling in order to provide a more reliable assessment of the biofuels chains.
\end{abstract}

Keywords: Sustainability / life cycle assessment / biofuels / land use change / uncertainty

Résumé - Importance du changement d'affectation des sols dans les bilans environnementaux des biocarburants. La contribution potentielle des biocarburants de première génération à l'atténuation des changements climatiques est largement débattue dans les arènes scientifique et politique. Ce potentiel est souvent évalué par l'analyse en cycle de vie (ACV), méthode permettant de comptabiliser les émissions de gaz à effet de serre (GES) "du berceau à la tombe" d'un produit, et qui est largement utilisée pour l'aide à la décision en matière environnementale. Cependant, l'utilisation de l'ACV pour évaluer la performance environnementale des biocarburants conduit à des résultats peu concluants et marqués par une grande variabilité et incertitude. Ceci est principalement dû aux différences dans la quantification des impacts environnementaux liés à la production des matières premières, ainsi qu'aux difficultés rencontrées lorsque les effets des changements d'affectation des sols (CAS) sont pris en compte. Le déclenchement des mécanismes de CAS est en partie la conséquence des politiques encourageant le déploiement à grande échelle des biocarburants dans le secteur des transports, ce qui accroît implicitement la concurrence entre les différentes utilisations possibles des terres à l'échelle de la planète. Dans cette étude, nous passons en revue les différentes méthodes récemment utilisées pour inclure les effets des CAS, avec des exemples de résultats extraits d'études américaines, européennes et françaises. Ces analyses croisées montrent que l'ACV doit être adaptée et combinée à d'autres méthodes d'évaluation telles que la modélisation économique afin de fournir une évaluation plus fiable des filières biocarburants.

Mots clés : Durabilité / analyse en cycle de vie / biocarburants / changement d'affectation des sols / incertitude

\section{Introduction}

The use of bioenergy in the transport sector is one of the solutions proposed by policy-makers to mitigate climate change and promote energy security. In the short to medium term, the

\footnotetext{
a Correspondence: wbenaoun@grignon.inra.fr
}

European union (EU) aims to deploy first generation biofuels, especially biodiesel and ethanol in order to replace fossil fuel and reduce anthropogenic emissions of greenhouse gases (GHG). Earlier studies (Farrel et al., 2006; Wang, 2005) concluded to a significant abatement of GHG emissions when substituting petroleum-based fuels with biofuels, which prompted the development of biodiesel and ethanol. However, recent 


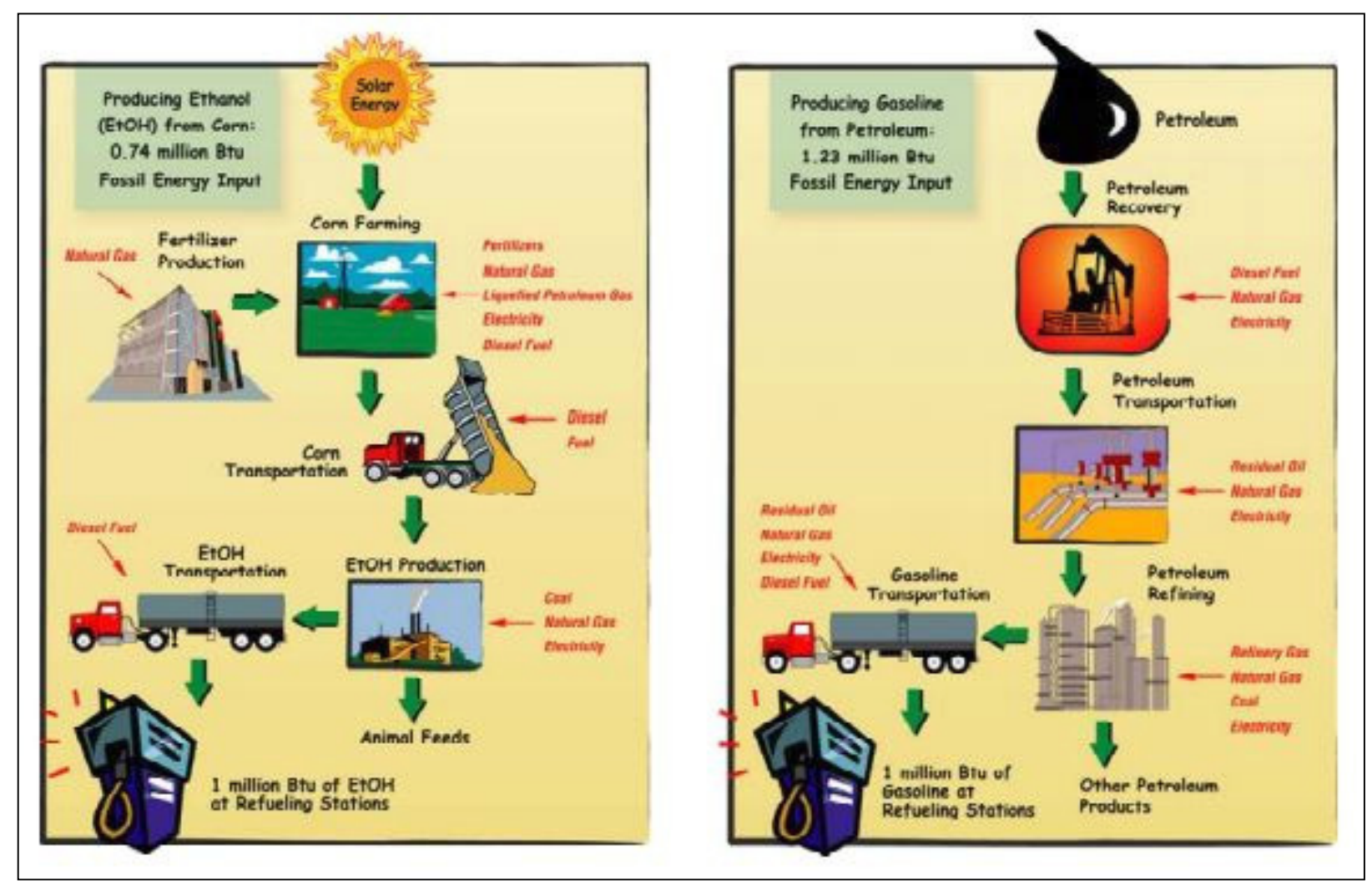

Fig. 1. Fossil fuel vs. biofuel life cycles (Wang, 2005).

pieces of research (Fargione et al., 2008; Searchinger et al., 2008) have suggested that policies supporting biofuels deployment should be revised in order to limit the unintended impacts of biofuel expansion, whereby the displacement of food crops by energy crops not only leads to direct land use changes (dLUC) but also to indirect land uses changes (iLUC). These complex mechanisms are difficult to estimate and are usually associated with detrimental effects on the environment, such as increased emissions of GHG and biodiversity depletion from the conversion of natural ecosystems. Thus, they are likely to severely degrade the environmental performance of biofuels.

Life-cycle assessment (LCA) is currently the most widelyused method to assess the environmental sustainability of biofuels, in particular for policy-making purposes. However, most published LCA studies on biofuels do not take into account iLUC effects (Di Lucia et al., 2012). This is in fact due to the inability of classical (also called attributional) LCA to take into account such effects, since it ignores the market and economic implications of a given decision (eg, to achieve a given blending target for biofuels at a national level). Economic equilibrium models and the so-called consequential approach to LCA have been promoted as a more suitable alternative to include these effects and produce a robust assessment of biofuels environmental impacts (Kløverpris et al., 2008). Although there is a consensus on the fact that LUC effects need to be addressed, the resulting indicators are quite heterogeneous and subject to high uncertainty (De Cara et al., 2012).

The EU is increasingly concerned with this issue and is currently expecting more reliable results to frame its biofuel policy. A directive on renewable energies was released by the European Commission (EC) in 2009, introducing sustainability criteria to be assessed when producing biofuels (EC, 2009; EC, 2010). However, its support of first-generation biofuels was recently questioned (EC, 2010).

The goal of this study is to underline the importance of using LCAs to evaluate the environmental burdens associated to biofuels chains, and the necessity of adapting this methodology in order to allow taking into account the effects of LUC. This work also focuses on identifying the sources of variability and uncertainty of existing studies.

\section{LCA: a suitable tool for environmental assessment}

\subsection{Main concepts of an LCA}

LCA is defined as the compilation and evaluation of the inputs, outputs and potential environmental impacts of a product system throughout its life cycle from the extraction of raw materials through production and use to waste management (Curran, 2013) (Fig. 1).

LCA technique can be used for different purposes. Its results allow the identification of opportunities to improve the environmental performance of products and provide a sound scientific basis for decision makers. This is due to the relevance of its indicators, as well as to its characteristics of objectivity and transparency. 
Conducting the LCA must be consistent with the methodology proposed by the ISO 14040 series (ISO, 2006a; 2006b). We describe the main steps of LCA in the following paragraph.

\subsection{Steps of an LCA}

LCA is an iterative process divided into four interrelated stages: the goal and scope definition, the inventory analysis, the impact assessment, and the interpretation.

The first phase consists in determining the objectives and the rationale for carrying out the assessment. This sets the scale of the study and establishes system boundaries. The functional unit (FU) is also chosen during this step. It measures the performance of the service provided by the product and is used as reference unit when calculating all the environmental impacts. For biofuels, functional units are typically $1 \mathrm{MJ}$ of biofuel energy content or $1 \mathrm{~km}$ travelled in a passenger car.

The second step in the LCA involves the inventory of inputs, outputs and environmental emissions of all components (or subsystems) of the system delineated in the previous stage. The associated flows (of materials, energy, information, etc.) are listed for each subsystem and expressed on the basis of the FU.

The impact analysis phase assesses the environmental impacts of inputs and outputs of the system studied, by aggregating the flows of the life cycle inventory into a set of impact categories, weighing all substances relative to a reference substance for each of these categories. For instance, the reference substance for the global warming impact is carbon dioxide $\left(\mathrm{CO}_{2}\right)$, and nitrous oxide (another greenhouse gas) will be given a weight of 296 corresponding to its global warming potential relative to $\mathrm{CO}_{2}$ (ADEME, 2010).

Interpretation phase is a key stage in which the robustness of the results is evaluated. This allows determining the main conclusions, limitations and recommendations borne out of the LCA study.

\subsection{Application to biofuels: attributional vs. consequential LCA}

In the recent literature on LCA, two approaches are distinguished. Attributional, also called retrospective LCA (aLCA) provides information about the environmental properties of a particular life cycle, and its subsystems. It thus seeks to describe the environmental impacts of past, current or potential future product systems, independent of other products or systems that could be affected by their development. Consequential, also called prospective LCA (cLCA) provides information on the environmental consequence of individual actions, eg the deployment of such products (Ekvall and Weidema, 2004).

In aLCA, the system investigated is restricted to a single life cycle from cradle to grave. Technical data on the various sub-systems of the life-cycle are averaged across the geographical domain considered to determine mean environmental burdens per unit of product considered.

Co-products associated with the product of interest are handled by applying allocation factors or using system expansion (Wang et al., 2011). In the case of biofuels, it is thus permitted to allocate a portion of the environmental burdens due to agricultural feedstock production and the first steps of the industrial processing to the co-products. The energy allocation remains the most commonly used method in the handling of co-products (Wang et al., 2011).

At this level, aLCA seems able to provide a comprehensive assessment of biofuels life cycles, since all the effects directly resulting from their production are taken into account (Reinhard and Zah, 2011). However, with the development of first generation biofuels sector in Europe and in the United States (US), it was found that their production entails largescale modifications of terrestrial ecosystems and biospheric fluxes through indirect market mechanisms (Fargione et al., 2008; Mellilo et al., 2009; Searchinger et al., 2009).

Consequential LCA can address these effects by simulating a "shock" in biofuel demand. It expands the system to include the life cycles of products affected by a change of the physical flows in the central life cycle. So it analyzes the system beyond the classical boundaries of the biodiesel value chain (from feedstock production to combustion in a vehicle), by encompassing the effects of fossil fuel substitution on other sectors or markets (e.g. food and feed commodities). In addition, regarding co-products, cLCA avoids allocation and thus should ideally model displacement of alternative products as a result of dynamic market interactions. Consequential LCA relies on marginal data as opposed to average data for aLCA (Ekvall et al., 2005).

The study of Searchinger, et al. (2008) illustrates the variation of LCA results in the case of biofuels according to the approach used. The results obtained with the attributional approach encourage the development of bioethanol from cornbased ethanol in the US, while those from the consequential approach point to an increase in GHG emissions if ethanol is to substitute gasoline. This difference is mainly due to the inclusion of the iLUC effects and the conversion of natural ecosystems to arable land.

\section{Land use changes due to biofuels development}

Taking both the direct and indirect effects of biofuels development into account is essential to improve the environmental assessment. Is the use of LCA methodology sufficient to provide an accurate estimation of the biofuels environmental performance?

Changes in land-use are the most important consequence of biofuels production (Van Stappen et al., 2011). Thus, the environmental assessment quality depends strongly on the way in which the magnitude of these mechanisms and their environmental effects are measured.

In this section we review current knowledge of LUC in relation to biofuel development, with a focus on their complexity and on the characteristics of each type of LUC. We also present the different methods used for their estimation.

\subsection{Types of land use changes}

The development of biofuels creates additional opportunities for economic agents. In fact, the increase in demand for a 
given biofuel feedstock will create a shortage of this product, which increases its price and thus provides an incentive for the farmer to increase its production. Farmers respond to this situation by intensifying crop management to improve yields. They may also transform uncultivated lands (e.g. natural areas, fallow) into arable land and/or substitute food/feed crops by energy crops (Reinhard and Zah, 2011).

The expansion of land devoted to energy crops and the displacement of food crops trigger LUC mechanisms. Here, we distinguish two types of LUC: dLUC and iLUC.

\subsubsection{Direct land use changes (dLUC)}

Direct land use change takes place when biofuels feedstock cultivation modifies the land use (De Cara et al., 2012). According to Gawel and Ludwig (2011), this type of LUC occurs when biomass cultivation displaces a different former land use (e.g., an arable crop grown on a former grassland). For Van Stappen, et al. (2011), dLUC describes the introduction of a new cropping system in a site where this form of cultivation has not taken place before. It may be estimated quantitatively from the changes in soil and vegetation carbon stocks.

If the biofuel market only changes the valorization of a given crop (i.e. switching from a food to energy en-use), the local impacts are considered negligible. On the other hand, if energy crops displace other crops in a cropping system, the effects on environment may be significant. Lastly, if feedstock production occurs on land with high carbon stocks (e.g. pasture, peat land, unmanaged forests), the dLUC effect is expected to be adverse. Conversely, when biofuel feedstock are grown on degraded soil, dLUC can contribute to improving the soil carbon balance (Gnansounou et al., 2008).

Several studies (EC, 2009; Hamelinck et al., 2008) focused on GHG emissions due to dLUC. Their results show that GHG emissions due to dLUC can be positive or negative depending on the type of land use prior to the implementation of energy crops (Van Stappen et al., 2011).

\subsubsection{Indirect land use change (iLUC)}

The development of first generation biofuels inevitably increases the pressure on land uses worldwide, and ultimately brings into cultivation lands that otherwise would not have been put to this use (Delucchi, 2011). iLUC occurs when additional demand for bioenergy feedstock induces a change in land use on other places via market mechanisms in order to maintain the same production level of food/feed crops (De Cara et al., 2012; Van Stappen et al., 2011). According to Gawel and Ludwig (2011), iLUC occurs when land that was formerly used for the cultivation of food, feed or fibre is now used for biomass production, shifting the original land use to an alternative area that may have a high carbon stock.

Contrary to dLUC, it is often impossible to quantify iLUC associated to bioenergy development, since it is a mechanism that can occur outside the country having fostered the production of biofuels. For example, Laurance (2007) showed that the increase of corn planting in the US may affect result in deforestation in the Amazon region. Thus, iLUC can cause important GHG emissions, with also adverse effects on biodiversity as well as on soil and water quality.

\subsection{Complexity of the mechanisms}

Theoretically, both direct and indirect LUC mechanisms appear quite simple. As shown in the previous section, any increase in biofuel production ultimately requires diverting cropland to the production of biofuel feedstock, which inevitably causes dLUC and iLUC.

For example (Fig. 2), an additional demand for rapeseed (crop A) used to produce biodiesel is met through two main market responses: an increase in current yields and an expansion in the cultivation area of rapeseed to ensure biodiesel production. With the second option (land expansion), rapeseed historically grown on existing agricultural land can be diverted to biodiesel production. This type of dLUC reduces agricultural area of rapeseed used in food, which has to be produced in some other land, incurring an iLUC effect. Rapeseed may also be grown on non-agricultural land (e.g., fallow and grassland). This type of dLUC is generally not accompanied by iLUC. Expansion of rape production can also be met by displacing other crops (crop B) on existing agricultural land. This can trigger iLUC in order to satisfy the demand in the displaced crops. One should mention that the production of biodiesel from rapeseed also allows meal production (co-product C) that can substitute other products used in animal feeding from another crop (crop D). This substitution reduces surface on which crop D is cultivated and therefore mitigates iLUC (Bauen et al., 2010).

We emphasize the importance of addressing LUC issues especially for iLUC on a global scale to allow taking into account the overall consequences of biofuels production (Di Lucia et al., 2012; Reinhard and Zah, 2009; Van Stappen et al., 2011).

The increase of pressure on land and the crops displacement that occur in major exporting countries such as Europe and the US change the market balance of products from these crops and thus affect their prices (De Cara, et al. 2012). This has an effect on farmers' decisions regarding the allocation of land worldwide.

In other words, as long as crops are displaced, the effects of displacement trickle through the overall global agriculture system until it reaches a new equilibrium (Delucchi, 2011; Reinhard and Zah, 2009).

Moreover, these new equilibria may promote substitution among several products (e.g., palm oil may substitute rapeseed oil used for biodiesel production). This makes the LUC mechanisms increasingly complex and their monitoring difficult to the point that the estimation of their environmental impacts is impossible (Overmars et al., 2011). Furthermore, one should mention that LUCs are also driven by several other factors such as biophysical, demographic and economic forces. Thus, attempting to attribute LUC to a single factor or the isolation of LUC only due to biofuels production reveals serious problems (De Cara et al., 2012; Gnansounou et al., 2009).

At European level, GHG emissions from dLUC may be assessed on the basis of the guidelines developed by the 


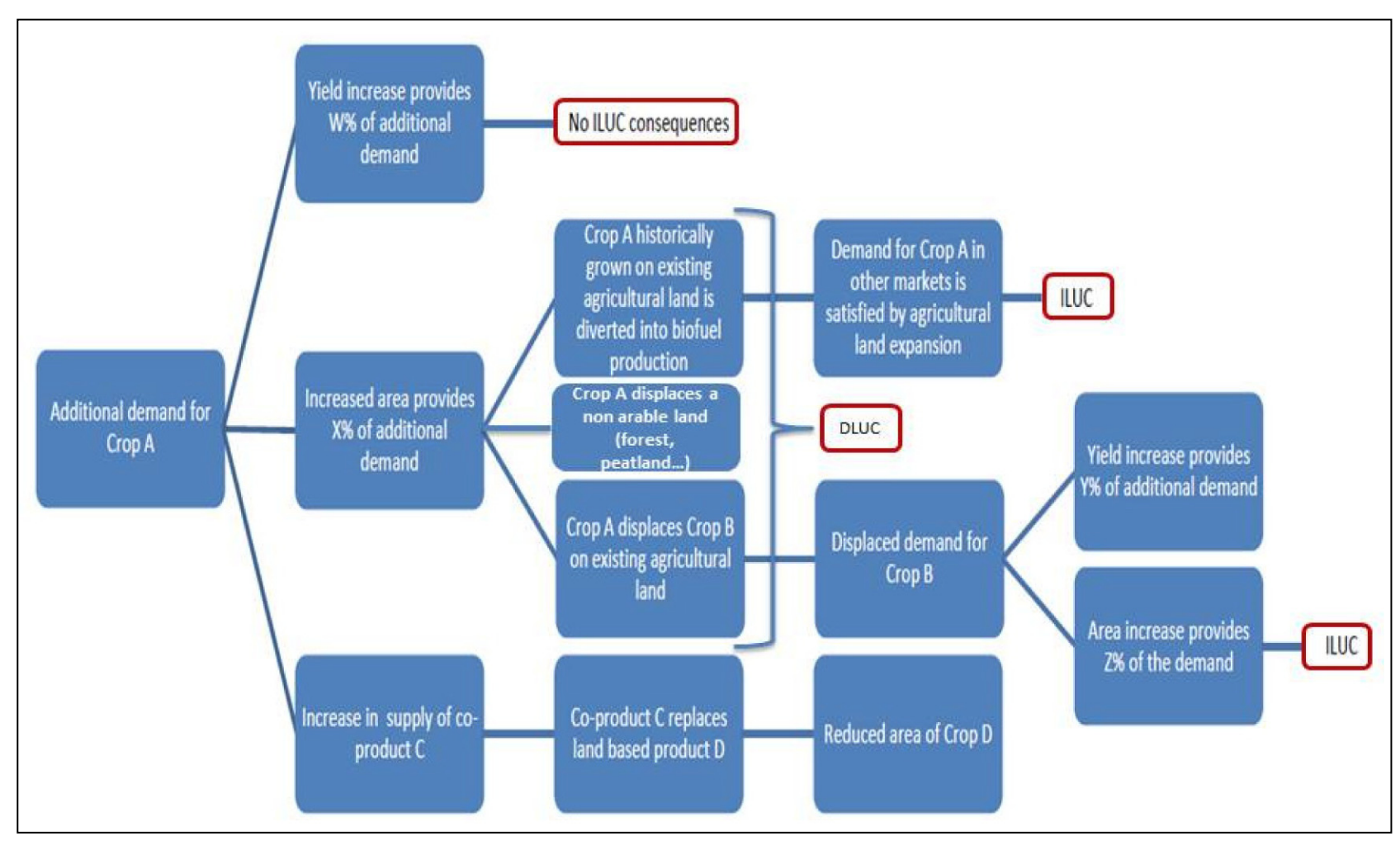

Fig. 2. Consequences of an increase in biofuels production (adapted from Bauen et al., 2010).

intergovernmental panel on climate change (IPCC), which propose default emissions factors (Tier 1) but also recommend using country-specific validated data (Tier 2 or 3 ) wherever available (Van Stappen et al., 2011). Unfortunately, the complexity of above-mentioned mechanisms leads to the fact that there is currently no consensus on one method for estimating GHG from iLUC (Gawel and Ludwig, 2011; Plevin et al., 2010), despite the general awareness that neglecting or over/under estimate of iLUC effects leads to wrong decisions and to an inefficient use of biofuels.

\subsection{Land use change estimation}

With the awareness of their importance in the environmental balances of biofuels, LUC effects are currently widely investigated, and estimated using different approaches, which are reviewed in the following section.

\subsubsection{Monitoring: use of historical data and statistical analysis}

Historical data from different sources may be collected and analyzed from a statistical viewpoint to identify possible relationships between biofuel production rates in a given country and land use and land use change. The use of this method is often justified by the fact that if biofuel production in a given country did trigger land conversion elsewhere, evidence for
LUC effects should be traceable in past data on land-use worldwide (Kim and Dale, 2011; Overmars et al., 2011). Some studies have attempted to find evidence for LUC from historical data. A recent study was conducted by In Numeri (2012) on behalf of the French agency for environment and energy management (ADEME) to identify the impacts of biofuel production in France on the French and international markets (imports, exports, prices, etc.), as well as on LUC. It concludes that LUCs in France are relatively limited, but it leads to inconclusive results concerning LUCs in countries outside the European Union. Also on behalf of ADEME, Chakir and Vermont (2013) analyzed the evolution of land use and dLUC generated by the development of energy crops and food crops in France during the last two decades, based on data from annual landuse surveys TERUTI (AGRESTE, 2004) and TERUTI LUCAS (AGRESTE, 2010). This study showed that until 2004, the increase of energy and food crops areas was limited to agricultural land while from 2006 on the expansion of these surfaces also impacted permanent grassland.

This approach was used by Kim and Dale (2011) to detect evidence for iLUC that might be caused by biofuel production in the US through a statistical analysis. This kind of analysis seems not to be sensitive enough to detect iLUC due to biofuel development. In contrast, Overmars, et al. (2011) used the same approach with a set of assumptions and concluded that emissions from iLUC could shift the GHG balance for biofuels from a net abatement to a net surplus of emissions relative to fossil fuels.

These retrospective and ex-post analyses are useful to illustrate the complexity of LUC mechanisms, but usually do 
not allow the isolation of LUC due to biofuels development from simple statistical analyses (De Cara, el al. 2012; Di Lucia et al., 2012; Overmars et al., 2011). Assumptions (e.g. on where the iLUC is likely to occur) must be made in order to obtain some uncertain conclusions.

\subsubsection{Expert based opinions}

As indicated above, statistical analyses of historical data are not sufficient to isolate and quantify the impact of biofuels production on LUC. The understanding of the mechanisms and the consultation of expert opinion remain essential to be able to locate the LUC (notably iLUC) and predict their magnitude. This method, also called "causal descriptive" is known for the transparency of its assumptions, often based on intuitive cause -effect relations, and its simplification of market mechanisms (Bauen et al., 2010; Fritsches et al., 2010; Nassar et al., 2011).

Such approaches are often used in consequential LCA. For example, Reinhard and Zah (2011) made some assumptions based on expert opinions to define a priori the crops displaced by biofuels feedstock, as well as the origin of the products to be imported to offset the decline in rapeseed oil diverted into biodiesel production in Switzerland.

\subsubsection{Economic equilibrium models}

In practice, it is impossible to isolate the impact of biofuels development on land use change from historical data or experts based opinions as there are other activities that can lead to exchanges in land use. Moreover, these methods simplify market mechanisms so that the prediction of LUC (especially of iLUC) might be not accurate enough. Actually, modeling seems to be the most successful method for measuring both direct and indirect LUC (Edwards, et al. 2010). Quantitative assessments based on models have been the policy makers' preferred methodology, even if they always blame their lack of transparency compared to LCA. Today general consensus exists about using economic approach to address iLUC (Di Lucia et al., 2012). This approach consists of using economic equilibrium models, which are complex optimization models based on the assumptions of perfect markets reaching equilibrium when demand equals supply in the studied economy. The response of supply and demand to price changes is the basis of the estimate of the LUC. These models make it possible to pinpoint the consequences of an additional demand for biofuels on land use at global scale, provided they include a land-use module and some degree of spatial differentiation between world regions. Here, we separate between two types of equilibrium models: partial and general equilibrium models.

\subsubsection{Partial equilibrium models}

The partial equilibrium models address a particular economic sector. Those who represent the agriculture describe the different compartments of commodities supply (yields, areas allocated to different cultures, imports) and demand (human/animal demand, non-food demand, and exports). They estimate land demand for individual crops and allow them to compete for land through cross-price elasticity. They subsequently calculate prices that balance supply and demand in all markets represented and their evolution over time within a given time horizon (Nassar et al., 2011).

The main partial equilibrium models are FAPRI, FASOM, CAPRI, IMPACT, GLOBIOM, AGLINK-COSIMO, and MIST.

\subsubsection{General equilibrium models}

General equilibrium models address all economic sectors and are developed to describe the international trade. Interactions between different markets are recognized endogenously in the model. It can be assumed that land is relatively easily transformed from one use to another through the definition of a constant elasticity of transformation. These models also include a representation of the yields response to price and make the differentiation between the yields from new lands and those from land already cultivated. Thus, the farmer will choose between increased business through the adjustment of production factors use levels (labor, fertilization, etc.), or expansion on other land to meet the demand due to the development of biofuels.

The main general equilibrium models are GTAP, LEITAP, and MIRAGE (De Cara et al., 2012).

Here, one should emphasize the necessity to incorporate geo-referenced information as inputs in economic models, especially regarding land cover and land availability. Certainly, with a finer spatial resolution, the estimation of GHG from LUC is the more accurate. It is also crucial to use biophysical models in combination with economic models in order to provide necessary information on yields and GHG emissions.

\section{Available estimations for LUC effects}

\subsection{Main results}

\subsubsection{At French level (studies commissioned by ADEME)}

By means of a sensitivity analysis trough a wide range of scenarios, the LCA of biofuels consumed in France (ADEME, 2010) highlighted the large sensitivity of their GHG balances to LUC hypothesis. Figure 3 shows the variation range of GHG emissions associated with different LUC hypothesis in a sensitivity analysis on GHG balance of soy biodiesel. Yellow bar represent gasoil GHG emissions, red bar GHG emissions for the soy biodiesel pathway considered and blue bars the GHG emissions for the different examined LUC scenario.

To contribute to improve knowledge on this topic, ADEME decided to work in partnership with the French rational institute for agricultural research (INRA) to provide additional analysis on ways of accounting for LUC in the GHG balance evaluation. In this section, the emphasis was placed on the different studies resulting from this collaboration and shared with representatives of public bodies, technical and scientific experts, and NGOs. The first step of this partnership was the launching at the end of 2010 with an international literature review carried out by INRA and a retrospective analysis of 


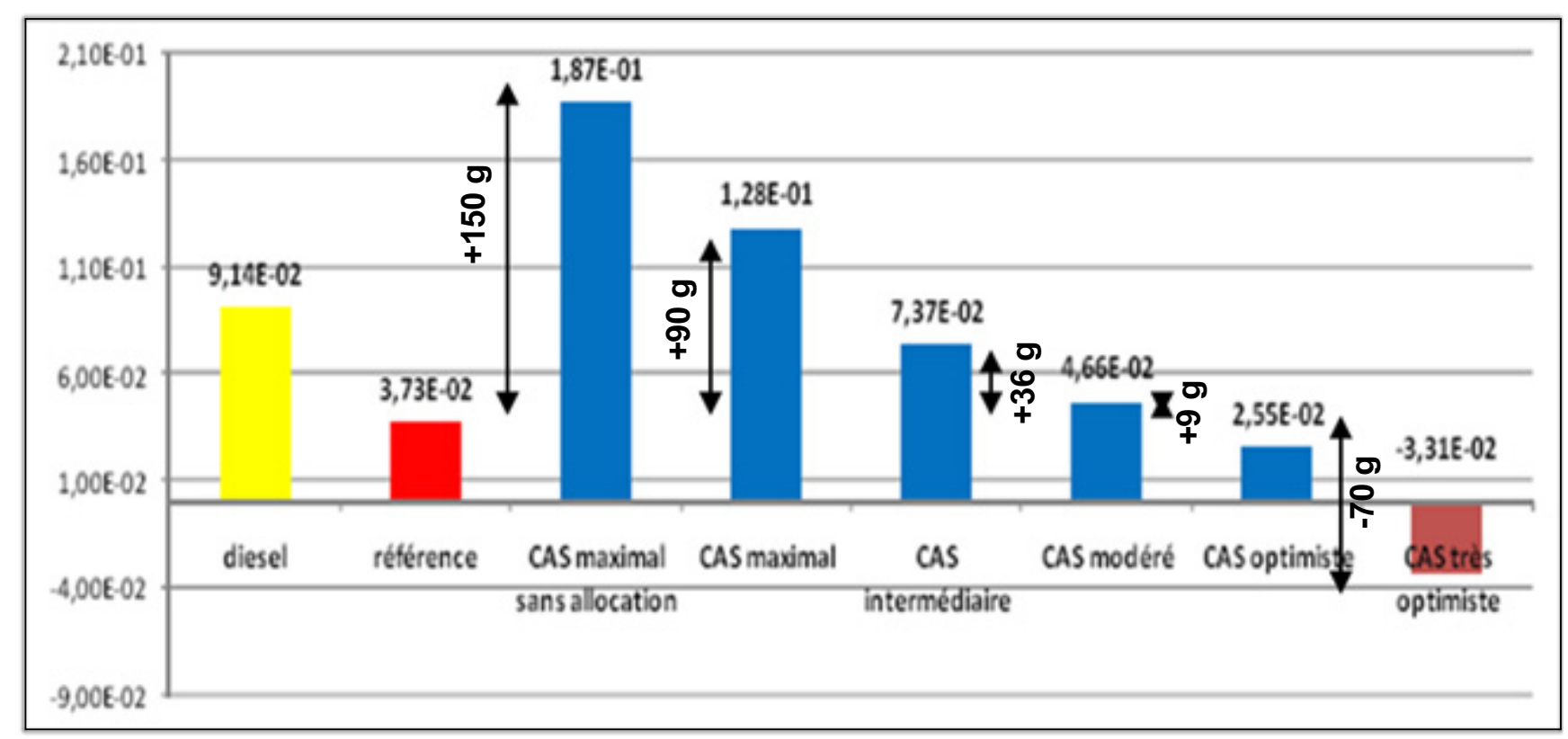

Fig. 3. Example of LUC sensitivity analysis on GHG balance of soy biodiesel (ADEME, 2010).

the impacts of French biofuel development policy since the 1990's. This dual approach enabled to study this question from different perspectives:

- in a prospective way, on a variable geographic scale, with various hypothesis especially on the LUC type, on feedstock mobilized, type of biofuels, by means of an international literature review;

- in retrospect, focusing at French level to examine the impacts of a national biofuel policy on a given period, with definite biofuel pathways and LUC types.

The retrospective analysis is described below in terms of aims, scope, methodology and main results and outcomes. General trends emerging from the review of international literature are given in Section 3.1.2.3, while a particular focus is given to a set of key studies deemed particularly representative of current literature in Sections 3.1.2.1 and 3.1.2.2. In those studies only the evaluations of global LUC factors or GHG balances pertaining to biodiesel pathways are presented here, in line with this special issue.

Based on the above-mentioned results from the sensitivity analysis on LUC scenarios in France (ADEME, 2010), it seemed interesting to investigate whether the development of biofuel consumption in France between 1993 and 2009 could have induce impacts on French and global markets of agricultural raw materials, processed products and co-products and LUC (direct or indirect). This survey was carried out by combining complementary approaches, presented in ${ }^{1}$ :

1 The first studies are completed and downloadable on ADEME website (http://www2.ademe.fr/servlet/KBaseShow? sort $=-1 \backslash \&$ cid $=96 \backslash \& m=3 \backslash \&$ catid=23698). The last one is still running, results in final validation phase and should be published by ADEME on the same web site during the second quarter of 2013. (i) data collection, statistical analysis in order to identify correlation between data series, evaluation of areas needed for production of raw materials (In Numeri, 2012);

(ii) analysis of land cover and land use changes in France (Teruti and Teruti-Lucas), evaluation of GHG emissions associated to biofuel consumption development: assessment of direct LUC in France (Chakir and Vermont, 2013);

(iii) economic modeling at France, European and global levels with a partial equilibrium model focused on crops: investigation of LUC and iLUC.

The first study (In Numeri, 2012) mainly evidenced the growing part of imports of raw materials (oils or oilseeds) used for biodiesel production between 2006 and 2009. The resulting LUC in France appeared relatively limited, essentially corresponding to the reversal of land set-aside in 1992. In other areas of the world, contrasting situations were observed. However, the statistical analyses did not make it possible to conclude about the associated impacts in terms of GHG emissions and thus to estimate global LUC factors. This confirms the difficulty if not impossibility in the absence of modeling to determine the sole responsibility of biofuels in the evolution of cropland evolution, crop management and land use changes.

The second study (Chakir and Vermont, 2013) confirmed that the increase in cropland area dedicated to energy use (rapeseed, sunflower, wheat and sugar beet) in France between 1992 and 2010 remained limited to existing agricultural land through the cultivation of land that had been set-aside from 1992 on, and to a lesser extent the conversion of grassland to arable land. For winter rapeseed, the increased crops area was obtained through re-allocations within existing arable land. The growth in sunflower area was done at the expense of mixed areas between livestock and crops with a slightly higher conversion rate of grassland towards cropland. An attempt at 
Table 1. Direct and indirect LUC factors (g eq. $\left.\mathrm{CO}_{2} / \mathrm{MJ}\right)$, computed over a 20 year period for various biodiesel pathways (source: Laborde 2011).

\begin{tabular}{ccc}
\hline Biodiesel & Without trade liberalization & With trade liberalization \\
\hline Rapeseed & 54 & 55 \\
Sunflower & 52 & 53 \\
Soy & 56 & 57 \\
Palm & 54 & 55 \\
\hline
\end{tabular}

Table 2. Direct and indirect LUC factor in $\mathrm{g}$ eq. $\mathrm{CO}_{2} / \mathrm{MJ}$ computed over a 20 year period for several biodiesel pathways.

\begin{tabular}{ccccc}
\hline & (Marelli et al. 2011)* & \multicolumn{4}{c}{ (Edwards et al. 2010) } \\
\hline Biodiesel & & FAPRI & GTAP & LEITAP \\
Rapeseed & $51.6-56.6$ & $73-221$ & $57-73.6$ & $338-353$ \\
Sunflower & $56.2-60.4$ & - & - & - \\
Soy & $51.5-55.7$ & - & - & - \\
Palm & $54-55$ & - & $14-78$ & $75-368$ \\
\hline
\end{tabular}

${ }^{*}$ Range of values corresponding to different values of soil organic carbon content.

evaluating a dLUC factor was made for the 2007-2010 time slice on the hypothesis that the dLUC structure was similar between the whole area cropped to rapeseed or sunflower and the area dedicated to energy feedstock. This lead to the following ranges: 0.2 to $0.6 \mathrm{~g}$ eq. $\mathrm{CO}_{2} / \mathrm{MJ}$ for rapeseed biodiesel and 0.7 to $1.9 \mathrm{~g}$ eq. $\mathrm{CO}_{2} / \mathrm{MJ}$ for sunflower biodiesel.

\subsubsection{At European and global level}

\subsubsection{Economic studies}

Carried out on behalf of the European Commission and published in autumn 2011, the IFPRI study (Laborde, 2011) used the economic general equilibrium model Mirage-Biof. It aimed at assessing the impacts (expressed as a dLUC + iLUC factor) of the forecast biofuel consumption patterns of the 27 member States of the EU in 2020 based on their respective National Renewable Energy Action Plans. Only first generation biofuels were considered. Table 1 lists the dLUC + iLUC factors obtained for different biodiesel pathways in two situations (without and with trade liberalization).

Several LUC studies were published in 2010 and 2011 by the Joint Research Centre of the EU (JRC). The work of Marelli, et al. (2011) is based on the evaluations of IFPRI with the same feedstock, production areas, biofuel types, biofuel demand patterns, feedstock, and time horizon. The main differences with the IFPRI study lie in the classification of certain crops as annual or perennial plants, the use of updated emission factors for some kind of soils (e.g. peatlands) and a finer categorization of available lands for cropland growth. The work of Edwards, et al. (2010) compared different economic models (FAPRI, GTAP, LEITAP), and considered different time horizons and biofuel consumption levels (Tab. 2).

US Environmental protection Agency (EPA) also published several studies in 2009 (USEPA, 2009) and 2010 (USEPA, 2010), focused on the impacts of US biofuel consumption targets at different time scales (2012, 2017 and 2022
Table 3. Direct and indirect LUC factor in $\mathrm{g}$ eq. $\mathrm{CO}_{2} / \mathrm{MJ}$ computed over a 20 year period for soy biodiesel.

\begin{tabular}{ccc}
\hline Biodiesel & USEPA 2009 & USEPA 2010 \\
\hline Soy & 154 & 48.5 \\
\hline
\end{tabular}

for ethanol and only 2022 for soy biodiesel), based on the FASOM and FAPRI models (Tab. 3).

\subsubsection{LCA studies}

Compared to economic studies on LUC effects, there are far fewer references available in the international literature review based on the LCA approach. We present below only those studies which present disaggregated dLUC and iLUC factors for different biodiesel pathways. Acquaye, et al. (2011) examined the case of rapeseed-based biodiesel when meeting the 2020 target of $10 \%$ of renewable energy in transportation sector in the EU. According to LUC type (grassland to cropland or forest to cropland), the respective estimated direct and indirect LUC factor is $26 \mathrm{~g}$ eq. $\mathrm{CO}_{2} / \mathrm{MJ}$ or $53.7 \mathrm{~g}$ eq. $\mathrm{CO}_{2} / \mathrm{MJ}$.

Table 4 compiles results of several studies, dealing with the biofuel policy of a particular country in Europe, considering different LUC types for different biodiesel pathways (rapeseed, soy, and palm).

\subsubsection{International literature review}

Recent study by De Cara, et al. (2012) surveyed the international literature on LUC and iLUC effects related to biofuel development, and aimed at evaluating their level and analyze their impacts on the GHG balances of biofuels. It focused on biodiesel (methyl esters) and bioethanol pathways. 485 references published between 1996 and 2011 were identified, 70 which were retained after an accurate selection, providing 239 direct LUC factors and 561 direct and indirect LUC factors.

The first conclusion drawn from this work was that LUC issue remains a recent scientific concern, which was still unknown when the French biofuel plans were launched and logically not taken account at the time.

The analysis of overall direct and indirect LUC factor shows some pretty clear differences according to raw material, biofuel types (1st $v s$. 2nd generation), supply area of raw materials, biofuel demand area, and methodology.

Among the 561 evaluations of overall LUC factor cited above, 221 involved biodiesel pathways, mostly based on rapeseed, soybean and palm oil. In order to get a better idea of these evaluations and potential impacts, these figures were added to the attributional life-cycle emissions of GHG of biofuels in France (ADEME, 2010) (Tab. 5).

It can be inferred from Table 5 that he medians values significantly impact GHG balances of biodiesel pathways may even offset their climate benefits. Thus, adding the median value to the corresponding LCA figure, vegetable oil based biodiesels would not appear to meet the RED sustainability criteria (which over time imposes minimum GHG abatement thresholds of 35, 50 and $60 \%$ compared to fossil diesel). 
Table 4. Direct and indirect LUC factor in g eq. $\mathrm{CO}_{2} / \mathrm{MJ}$ annualized on 20 years for different pathways and different national policy schemes in Europe.

\begin{tabular}{|c|c|c|c|c|}
\hline $\begin{array}{c}\mathrm{d}+\mathrm{i} \text { LUC (g eq. } \\
\left.\mathrm{CO}_{2} / \mathrm{MJ}\right)\end{array}$ & (Lechon et al., 2011)* & $\begin{array}{c}\text { (Reinhard and Zah) } \\
* *\end{array}$ & (Brandao, 2011)*** & $(\mathrm{ADEME}, 2010)^{* * * * *}$ \\
\hline Mix biodiesel Europe & $122-127$ & - & - & - \\
\hline Rapeseed & - & $\begin{array}{c}\quad-145-307 \\
\text { (Reinhard and Zah, 2011) }\end{array}$ & $-280-380$ & $-48-99$ \\
\hline Soy & - & $\begin{array}{c}\quad-85-125 \\
\text { (Reinhard and Zah, 2009) }\end{array}$ & - & $-38-444$ \\
\hline Palm & - & $\begin{array}{c}193 \\
\text { (Reinhard and Zah, 2009) }\end{array}$ & - & $-11,6-120$ \\
\hline
\end{tabular}

*Spain, raw material supply areas: Europe, US, Canada, Malaysia - LUC types considered (grassland-cropland, forest-cropland, others), different coproduct effect levels, **Switzerland, raw material supply areas: Switzerland, Brazil, Malaysia, ***UK, raw material supply areas: UKalternatively expansion, substitution of lands, intensification of crops, different LUC types, different biofuel consumption levels, ****France, raw material supply areas: Europe, Brazil, US, Malaysia, Indonesia, different LUC types.

Table 5. GHG balances and LUC factors for several biodiesel pathways.

\begin{tabular}{|c|c|c|c|c|c|}
\cline { 3 - 6 } \multicolumn{1}{c|}{} & \multicolumn{5}{c|}{ (d+i LUC) $\mathrm{g}$ eq. $\mathrm{CO}_{2} / \mathrm{MJ}$} \\
\cline { 3 - 6 } \multicolumn{1}{c|}{$\begin{array}{c}\text { ADEME, 2010 } \\
\text { (without LUC } \\
\text { scenario) }\end{array}$} & \multicolumn{4}{|c|}{ INRA study (De Cara et al., 2012) } \\
\cline { 5 - 7 } & 37.3 & 79 & 10 & 54 & 90 \\
\hline Rapeseed & 25.1 & 10 & 55 & 57 & 59 \\
\hline Sunflower & 21.1 & 64 & 56 & 80 & 168 \\
\hline Soy & 21.8 & 52 & 31 & 55 & 120 \\
\hline Palm & 8.7 & & & & \\
\hline UCOME & 8.4 & & & & \\
\hline FAME & 31.8 & 79 & 10 & 54 & 90 \\
\hline PVO & & & & & median \\
\hline
\end{tabular}

${ }^{*} n$ = number of references by pathway, UCOME : used cook oil methyl ester, FAME: fat animal methyl ester, PVO: pure vegetable oil, GHG balance for diesel $($ ADEME, 2010 $)=91.4 \mathrm{~g}$ eq. $\mathrm{CO}_{2} / \mathrm{MJ}(-35 \%=59.4,-50 \%=45.7)$.

\subsection{Variability of results}

Several studies (De Cara et al., 2012; Malça and Freire, 2011; Plevin et al., 2010) focused on comparing the available environmental assessments of biofuels. Their researches highlight the great variability of results from one assessment to another. For example, emissions associated to biodiesel chains life cycles vary from 15 to $170 \mathrm{~g} \mathrm{CO}_{2}$ eq./MJ. Estimations of both direct and indirect LUC factor (e.g. annualized GHG emissions divided by biofuel energy, expressed in $\mathrm{g} \mathrm{CO}_{2}$ eq./MJ) are among the main sources of variability. However interpreting this variation range of evaluations as the sole reflection of the uncertainty would be a mistake (De Cara et al., 2012). The apparent variability partly reflects the diversity of approaches (LCA vs. economic modeling), definitions and hypothesis in scenario concerning LUC type and original land cover, biofuel pathway, feedstock types and origin, level of mandates, and representation of market mechanisms used in different works. Significant variability is also observed between the results from studies using the same method. When working with LCA methodology, variability between different studies is due to a difference in the choice of approach (attributional or consequential), the choice of system boundaries (well to tank or well to wheel), the choice of the functional unit and the co-products handling (allocation or substitution), while when working with economic models, results depend on the type (general vs. partial equilibrium) and the constructions of models.

A meta-analysis was made by De Cara, et al. (2012) especially in order to quantify the effect of different parameters on assessment of an overall direct plus indirect LUC factor. It shows that results are influenced by:

- the kind of method: LCA lead generally to LUC factor values lower than those provided by economic models;

- the biofuel pathway: all things being equal, bioethanol lead to LUC factor lower than biodiesel and lignocellulosic ethanol LUC factor seems to be lower than 1st generation ethanol;

- the LUC type: when scenario allows conversion of soils with high carbon content (peatlands or forests for example) all things being equal, it predicts significantly higher LUC factors; 


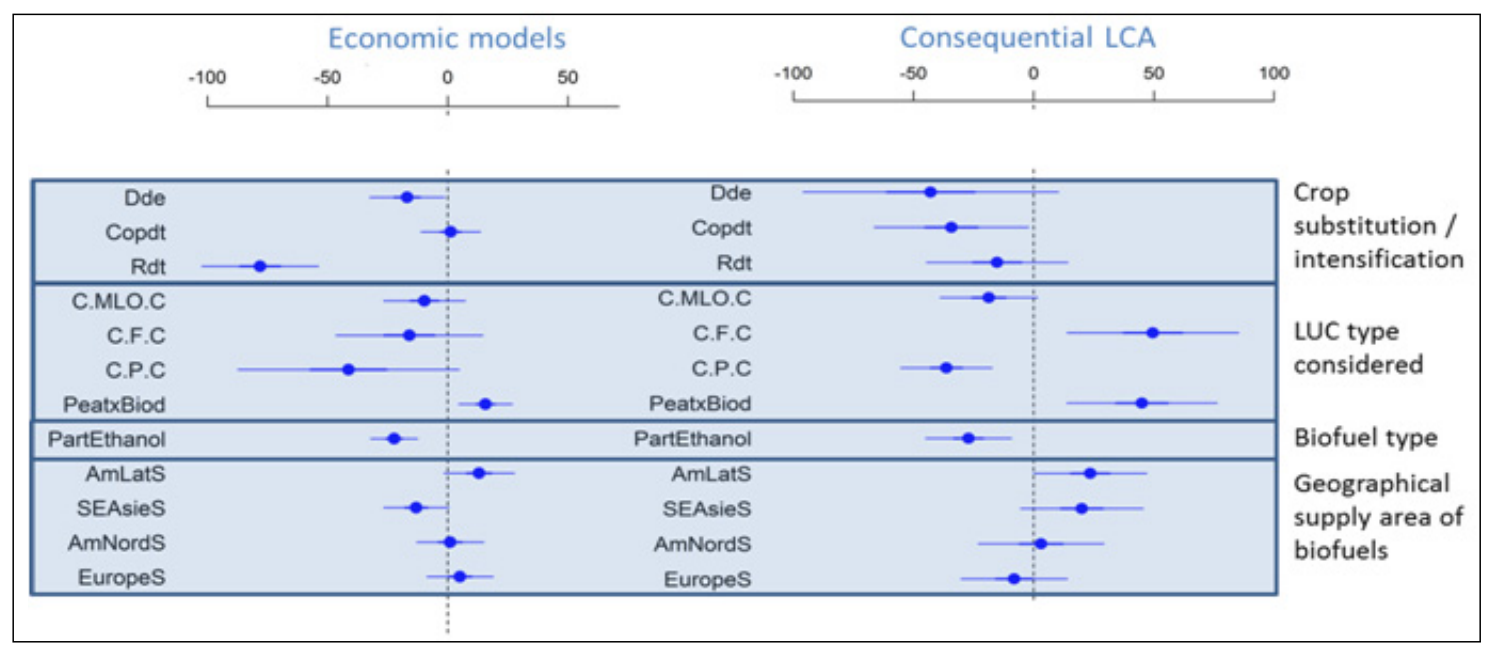

Fig. 4. Impact of different hypothesis on $\mathrm{d}+\mathrm{i} \mathrm{LUC}$ factor (g eq. $\mathrm{CO}_{2} / \mathrm{MJ}$ computed over a 20 year period) (De Cara et al., 2012). Partethanol: ethanol part (on energy basis) in the total biofuel mix examined. CFC, CPC, CMLOC: these parameters respectively indicate that the model or scenario allows the conversion of forest, grassland, marginal land (including savannah, mountain land) in cropland and conversely. PeatxBiod indicates that the scenario allows conversion from peat land and considers biodiesel production. Rdt is associated to crop yield and indicates here that crop yields are likely to change due to the increase of biofuel demand. Dde indicates that model considers the reaction of demand to price changes. Copdt indicates that coproducts are accounted in the study and gives rise to LUC credits. AmLatS, SEAsieS, AmNordS, EuropeS described the geographical supply area of biofuel, respectively: Latin America, South East Asia, North America and Europe. Models can consider several areas together.

- other hypothesis on agricultural yields and elasticity of food demand: scenarios that take into account the yield response and the variation of food demand as a function of prices all things being equal result in lower evaluations of LUC factor (Fig. 4).

\subsection{Sources of uncertainty around LUC factors}

Many studies on the GHG balances of biodiesel concur in the large uncertainties revolving around the emissions of GHG in the agricultural phase, particularly for $\mathrm{N}_{2} \mathrm{O}$ (ADEME, 2010; Bird et al., 2011; Crutzen et al., 2007).

For the estimation of LUC factors, published studies have shown the importance of the reliability of the input data pertaining to both the raw material and biofuel production stages, trade monitoring, supply balances (In Numeri, 2012) and model calibration for sensitive adjustment factors such as hypothesis on display of land used for displaced crop production (De Cara et al., 2012). They also showed the need to improve the monitoring of direct LUC in all countries concerned by biofuel production and trade and the interest of existing tools as Teruti-Lucas survey (AGRESTE, 2010).

\section{Conclusion and outlook}

At European level, the development of the biofuels industry, particularly biodiesel, is a sensitive public policy issue. On the one hand, the large-scale deployment of first generation biofuels is quite promising in the sense that it enhances energy security and creates additional opportunities for farmers, in addition to the role that it can play in regional development. On the other hand, the sustainability of biofuels is being questioned since several studies pointed out that the effects of both direct and indirect land use changes triggered by the increase in demand for bioenergy could lead to adverse impacts on the environment.

Life cycle assessment is currently the most recommended methodology to aid decision-making on environmental issues. In this study, we emphasized the need to opt for consequential LCA, in order to encompass both direct and indirect impacts in the evaluation of biofuel chains.

Several approaches have been proposed to quantify the LUCs and assess their environmental effects. However, there is still no consensus on a given method. Indeed, consequential LCA use expert opinions and statistical analysis of historical data to estimate LUC and are often criticized because of the use of simplifying assumptions of market mechanisms, while economic equilibrium models, although they provide strongest estimates of these mechanisms are criticized because their difficulty of use (by non-specialists) and their often lack transparency. Thus, ensuring an optimal social welfare with biofuels development remains quite difficult.

To generate a more robust assessment of the environmental performance of biofuels, it will be essential to:

- properly assess and isolate land use changes due to biofuels. The use of an economic equilibrium (whether partial or general) model including a land use module with fine spatial resolution and running at a global scale seems to be the most accomplished method for achieving this goal;

- provide more accurate estimates of GHG emissions (including $\mathrm{CO}_{2}$ and $\mathrm{N}_{2} \mathrm{O}$ ) associated to biofuel feedstock production and LUC, via the use of ecosystem models adapted to local conditions;

- combine economic modeling and LCA, so as to overcome the difficulties related to the tracing of biofuel effects on land use, as observed in other LCA approaches. This will 
allow us to be more precise when estimating the environmental impacts related to agriculture and land use change. Here, we emphasized that these tools may complement each other. On the one hand, the use of results from economic models in consequential LCA would enhance the quality of iLUC estimation. On the other hand, completing economic models by a life cycle assessment would broaden the range of environmental indicators used to assess biofuels performance, including local impacts such as eutrophication, air quality or toxicity/ecotoxicity.

Parallel, some ways of improvement exist to reduce LUC factors. Measures to increase productivity in agriculture may indeed limit the expansion needed to meet the increased demand related to biofuels and indirect effects of LUC. Improved crop yields (particularly in areas where LUC can have strong impact on GHG emissions such as Latin America or South East Asia) and the energy efficiency of biofuels can reduce the pressure on land and therefore the indirect effects associated with LUC. Genetic improvement could also improve yields as well as reduce the use of inputs.

The technologies that enable to use residues, waste or other feedstock as raw material for biofuel production lie also among ways pointed by EC to reduce LUC and avoid crop displacement and food competition.

Finally, other ways highlighted in the recent Lepage report on biofuels (Lepage et al., 2013) concern the improvement of energy efficiency in transport and the wider use of other renewable energies to contribute to the $10 \%$ objective of renewable energy in final consumption of transportation sector in 2020.

\section{References}

Acquaye AA, Wiedmann T, Feng K, et al. 2011. Identification of carbon hot-spots and quantification of GHG intensities in the biodiesel supply chain using hybrid LCA and structural path analysis, Environ. Sci. Technol. 45: 2471-2478.

ADEME. 2010. Analyses de cycle de vie appliquées aux biocarburants de première génération consommés en France. Étude réalisée pour le compte de l'ADEME par BIO IS 2010, 1-236

AGRESTE. 2004. Enquête TERUTI - série 1992 à 2004. Service de la Statistique et de la Prospective (SSP) du Ministère de l'Agriculture, de l'Alimentation, de la Pêche, de la Ruralité et de l'Aménagement du Territoire.

AGRESTE. 2010. Enquête TERUTI-LUCAS - Nouvelle série 2005 à 2010. Service de la Statistique et de la Prospective (SSP) du Ministère de l'Agriculture, de l'Alimentation, de la Pêche, de la Ruralité et de l'Aménagement du Territoire.

Bauen A, Chudziak C, Vad K, Watson PA. 2010. causal descriptive approach to modelling the GHG emissions associated with the indirect land use impacts of biofuels: Final reports. E4tech, UK department of transport 2010.

Bird N, Cowie A, Cherubini F, Jungmeier G. 2011. Using a life cycle assessment approach to estimate the net greenhouse gas emissions of bioenergy, IEA Bioenergy, Strategic Report, ExCo:2011:03.

Brandão M. 2011. Food, Feed, Fuel, Timber or Carbon Sink? Towards sustainable land-use systems - a consequential life cycle approach, Ph.D. thesis, Centre for Environmental Strategy; Division of Civil, Chemical and Environmental Engineering; Faculty of Engineering and Physical Sciences; University of Surrey.
Chakir R, Vermont B. 2013. Étude complémentaire à l'analyse rétrospective des interactions du développement des biocarburants en France avec l'évolution des marches français et mondiaux et les changements d'affectation des sols. Étude réalisée pour le compte de l'ADEME par l'INRA, pp. 1-69.

Crutzen PJ, Mosier AR, Winiwarter W. 2007. $\mathrm{N}_{2} \mathrm{O}$ release from agrobiofuel production negates global warming reduction by replacing fossil fuels, Atmos. Chem. Phys. Discuss. 8: 11191-11205

Curran MA. 2013. Life cycle assessment: a review of the methodology and its application to sustainability. Curr. Opin. Chem. Eng. 2: $1-5$.

De Cara S, Goussebaïle A, Grateau R, et al. 2012. Revue critique des études évaluant l'effet des changements d'affectation des sols sur les bilans environnementaux des biocarburants. Étude réalisée pour le compte de l'ADEME par l'INRA, pp. 1-96.

Delucchi M. 2011. A conceptual framework for estimating the climate impacts of land-use change due to energy crop programs. Biomass and Bioenergy 35: 2337-2360.

Di Lucia L, Ahlgrem S, Ericsson K. The dilemma of indirect land-use changes in EU biofuel policy - An empirical study of policymaking in the context of scientific uncertainty. Environ. Sci. Policy. 2012: 9-19.

Edwards R, Mulligan D, Marelli L. 2010. Indirect land use change from increased biofuels demand: comparison of models and results of marginal biofuels production from different feedstocks, JRC-IE, 2010.

Ekvall T, Tillman AM, Molander S. 2005. Normative ethics and methodology for life cycle assessment. J. Clean. Prod. 13: 1225-1234.

Ekvall T, Weidema boP. 2004. System boundaries and input data in consequential life cycle inventory analysis. Int. J. LCA 3: $161-171$.

European Commission. 2009. Directive 2009/28/EC of the European Parliament and of the Council of 23 April 2009 on the promotion of the use of energy from renewable sources and amending and subsequently repealing Directives 2001/77/EC and 2003/30/EC. 2009. Available at: http://eur-lex.europa.eu/ LexUriServ/LexUriServ.do?uri=Oj:L:2009:140:0016:0062:en: PDF.

European Commission. 2010. Rapport de la Commission sur les changements indirects d'affectation des sols liés aux biocarburants et aux bioliquides. Available at: http://eur-lex.europa.eu/ LexUriServ/LexUriServ.do?uri=COM:2010:0811:FIN:FR:PDF.

Fargione J, Hill J, Tilman D, Polasky S, Hawthorne P. 2008. Land Clearing and the Biofuel Carbon Debt. Science 319: 1235-1237.

Farrel AE, Plevin RJ, Turner BT, Jones AD, O'Hare M, Kammen DM. 2006. O'Hare M, Kammen DM. Ethanol can contribute to energy and environmental goals. Science 311: 506-508.

Fritsches UR, Sims R, Monti A. 2010. Direct and indirect land use competition issues for energy crops and their sustainbale production - an overview. Biofuel Bioprod. Biores. 4: 692-704.

Gawel E, Ludwig G. 2011. The iLUC dilemma: How to deal with indirect land use changes when governing energy crops?. Land Use Policy 28: 846-856.

Gnansounou E, Dauriat A, Villegas J, Panichelli, L. 2009. Life cycle assessment of biofuels : Energy and greenhouse gas balances. Biores. Technol. 100: 4919-4930.

Gnansounou E, Panichelli L, Dauriat A, Villegas JD. 2008. Accounting for indirect land use changes in ghg balance of biofuels - Review of current approaches. Lausanne, Switzerland: École polytechnique fédérale de Lausanne, $22 \mathrm{p}$.

Hamelinck C, Koop K, Croezen H, Koper M, Kampman B, Bergsma G. 2008. Technical Specification: Greenhouse Gas Calculator for 
Biofuels. Utrecht, Netherlands: Ecofys \& CE Delft, commissioned by SenterNovem, $109 \mathrm{p}$.

In Numeri. 2012. Analyse rétrospective des interactions du développement des biocarburants en France avec l'évolution des marchés français et mondiaux (productions agricoles, produits transformés et coproduits) et les changements d'affectation des sols. Étude réalisée pour le compte de l'ADEME, pp. 1-128.

ISO. 2006a. ISO Norm 14040: Environmental management-life cycle assessment-principles and framework.

ISO. 2006b. ISO Norm 14044: Environmental management-life cycle assessment-requirements and guidelines.

Kim S, Dale BE. 2011. Indirect land use change for biofuels: Testing predictions and improving analytical methodologies. Biomass and Bioenergy 35: 3235-3240.

Kløverpris J, Wenzel H, Nielsen PH. 2008. Life cycle inventory modeling of land use induced by crop consumption. Part 1: conceptual analysis and methodological proposal. Int. J. Life Cycle Assess. 13: 13-21.

Laborde D. 2011, Assessing the land use change consequences of European biofuel policies. IFPRI.

Laurance WF. 2007. Switch to corn promotes Amazon deforestation. Science 318: 1721.

Lechon Y, Cabal H, Sáez R. 2011. Life cycle greenhouse gas emissions impacts of the adoption of the EU Directive on biofuels in Spain. Effect of the import of raw materials and land use changes. Biomass and Bioenergy 35: 2374-2384.

Lepage C. 2013. Projet de rapport sur la proposition de directive du Parlement européen et du Conseil modifiant la directive 98/70/CE concernant la qualité de l'essence et des carburants diesel et modifiant la directive 2009/28/CE relative à la promotion de l'utilisation de l'énergie produite à partir de sources renouvelables (COM(2012)0595 - C70337/2012 - 2012/0288(COD)), Commission de l'Environnement, de la santé publique et de la sécurité alimentaire.

Malça J, Freire F. 2011. Life-cycle studies of biodiesel in Europe: A review addressing the variability of results and modeling issues. Renew. Sust. Energ. Rev. 15: 338-351.

Marelli L, Ramos F, Hiederer R, Koeble E. 2011. Estimate of GHG emissions from global land use change scenarios, JRC Technical notes, JRC-IE.
Mellilo JM, Reilly JM, Kicklighter DW, et al. 2009. Indirect Emissions From Biofuels: How important? Science 326: 1397-1399.

Nassar AM, Harfuch L, Bachion LC, Moreira MR. Biofuels and land-use changes: searching for the top model. Interface Focus 1: 224-232.

Overmars KP, Stehfest E, Ros JPM, Prins AG. 2011. Indirect land use change emissions related to EU biofuel consumption: an analysis based on historical data. Environ. Sci. Policy. 14: 248-257.

Plevin RJ, O'Hare M, Jones AD, Torn MS, Gibbs HK. 2010. Greenhouse gas emissions from biofuels' indirect land use change are uncertain but may be much greater than previously estimated. Environ. Sci. Technol. 44: 8015-8021.

Reinhard J, Zah R. 2011. Consequential life cycle assessment of the environmental impacts of an increased rapemethylester (RME) production in Switzerland. Biomass and Bioenergy 35: 2361-2373.

Reinhard J, Zah R. 2009. Global environmental consequences of increased biodiesel consumption in Switzerland: consequential life cycle assessment. J. Clean. Prod. 17: S46-S56.

Searchinger T, Heimlich R, Houghton RA, et al. 2008. Use of US cropland for biofuels increases greenhouse gases through emissions from land-use-change. Science 319: 1238-1240.

Searchinger T, Hamburg SP, Melillo J, et al. 2009. Fixing a Critical Climate Accounting Error. Science 326: 527-528.

US Environmental Protection Agency. 2009. Draft regulatory Impact analysis: Changes to Renewable Fuel Standard.

US Environmental Protection Agency. 2010 Renewable fuel standard program (RFS2) regulatory impact analysis.

Van Stappen F, Brose I, Schenkel Y. 2011. Direct and indirect land use changes issues in European sustainability initiatives: Stateof-the-art, open issues and future developments. Biomass and Bioenergy 35: 4824-4834.

Wang M. 2005. Updated Energy and Greenhouse Gas Emission results of Fuel Ethanol. Center for Transportation Research, Argonne National Laboratory. Available at: http://www. transportation.anl.gov/pdfs/TA/375.pdf.

Wang M, Huo H, Arora S. 2011. Methods of dealing with coproductsof biofuels in life-cycle analysis and consequent results within the U.S context. Energ. Policy 39: 5726-5736.

Cite this article as: Wassim Ben Aoun, Benoît Gabrielle, Bruno Gagnepain. The importance of land use change in the environmental balance of biofuels. OCL 2013, 20(5) D505. 